\title{
The Idea of Woman in Fundamentalist Islam
}

Lamia Rustum Shehadeh

Gainsville: University Press of Florida, 2004. 321 pages.

Lamia Rustum Shehadeh's timely book, The Idea of Woman in Fundamentalist Islam, begins with a brief biography of influential "funda- 
mentalists." She examines the context in which they formulated their theories and the extent to which they influenced each other, a process that allows us to see their ideas as a response to the historical, political, and social environments in which they lived. For example, the Muslim Brotherhood, founded by Hasan al-Banna in 1928, not only helped formulate and consolidate Islamic revivalism in Egypt, but also helped provide a blueprint for a sociopolitical organization that promoted the political Islam or Islamism influencing chapters in Syria, Lebanon, Iraq, and Palestine. The ideas promoted by the Brotherhood also spread to Sudan, where they continue to guide the current regime's policies. In some cases, as in Iran and Sudan, pronouncements of these ideologues influence state law and public policy. At other times they challenge the state, as in Tunisia.

Al-Banna promotes the view that Muslim countries became impoverished and fell under European control because they have deviated from Islam. He suggests that Muslims see Islam as the solution to their problems. However, al-Banna and other Islamists believe that Islam's historical traditions are irrelevant for modern times. Instead, they propose a return to what they believe to be the traditions of the Prophet's time and that of the first four caliphs. Moreover, they advocate the use of ijtihad (independent judgment), a practice that allows them to interpret seventhcentury traditions in light of modern needs. Islamist ideologues reserve this practice for themselves, and thus largely marginalize its alternative uses by feminists and other progressive groups to advance women's rights or minority rights.

Islamist ideologues speak of the liberation and freedom that Muslim men and women can attain in the new Islamic order. Yet, it is men who are the major beneficiaries of these freedoms. Moreover, women as well as men have biologically determined roles. Men are the providers and women are to obey their husbands and focus on their primary roles of mother and wife. Women's sexuality is dangerous to society, and thus must be contained through the institution of marriage, which is under the control of men. The veil plays a central role in women's lives. To guard against tempting men, they are to be veiled at all times. Since women are given a limited role in the public sphere, their education needs to be limited to subjects that enhance their domestic role, unless it is in the interest of society for them to pursue a more broad-based education.

Even the powerful Islamist ideologue Zaynab al-Ghazali subscribes to these views. But she has two sets of rules: one for herself as the founder of the Muslim Woman's Association of Egypt, and another set for "regular" 
Muslim women who have few rights. Instead, their husbands are their leaders, elders, rulers, and punishers if they deviate from the "correct" path. Moreover, women who ask their husbands for a divorce are committing a criminal act. These rules do not apply to al-Ghazali, who has divorced two husbands.

This important book also draws links between the context in which the Islamists struggled and their pronouncements, so that we no longer see them as undifferentiated orientalist stereotypes, but rather as purposeful actors who were involved in local, national, and international struggles. Interestingly, Shehadeh's comments echo those of various Islamists in whom Muslims would find a perfect and comprehensive guide to living an "Islamic" life, for she begins her book with comments indicating her belief that Islam is a complete lifestyle and world order. In the ever-changing and increasingly interconnected world in which we live, this is a difficult position to sustain. Indeed, Shehadeh challenges her own view when she speaks about the various positions among Muslim "fundamentalists." Perhaps the problem is with the term fundamentalism itself. It is not a word that Islamic revivalists use to describe themselves. Instead, fundamentalism is a word that is frequently used to stereotype Muslims who are literalists and who seek guidance from the holy books as a blueprint for their lives. Such reductionism denies the fact that many non-Muslims are also literalists. An unproblematic use of the word fundamentalism might conflate the writings of Hassan al-Banna with those of Fazul-Rehman and Riffat Hassan (two revivalists whose views are not discussed in this book). This again leads me to ask why these particular writers were chosen? What is the common thread that connects them?

According to the author, the central tension for Muslims is Islam and the West. True, American-dominated western culture has spread worldwide, along with the forces of globalization. But not all of the Muslim world's struggles are with the West or with western culture. For example, India's Muslims struggle against rising Hindu nationalism and its increasing access to state power, while in the Philippines Muslim rebels are struggling against the brutal fist of the national state.

Although struggles for Muslim identities take local forms, there are global connections. Muslim societies are politically independent and yet continue to suffer from the long-lasting effects of colonialism, which have been exacerbated by the effects of globalization. These processes and their connections are not well-explored in the book. Although the author alludes to the links between rising fundamentalism and the failure of moderniza- 
tion and development programs in Muslim societies, she does not push this thought further and connect it to the rise of the religious movements worldwide and, in particular, to American foreign policy. I would argue that the rise of Islamic revivalism, as well as its influence on nation-state, has a spiritual component, but there are other factors as well. It is not only connected to the effects of colonial policies, international flows of capital, and the Third World's impoverishment, but also to American foreign policy initiatives. These crucial links are missing from Shehadeh's analysis.

Shehadeh also does not locate Islamist pronouncements on gender relations within a larger global patriarchal context. Had she done so, she would have noted that Islamist views on women are not all that different from the pronouncements of revivalists belonging to other faiths, nor are they all that different from the patriarchal views that feminists have struggled against in the West. Only ceaseless activism by feminists managed to change women's conditions in Europe to what they are today. By failing to connect Islamic patriarchy to the ways in which patriarchy has functioned globally, Shehadeh inadvertently reinforces orientalist stereotypes about Muslim "fundamentalists" as the ultimate violent and unique "other." As such, she risks strengthening stereotypes about Muslims. Furthermore, the author claims that she wants to formulate a "universal gender theory" (p. 12). Increasingly, feminists are moving away from a universal gender theory because it elides differences and silences those without power. I wonder what Shehadah's universal gender theory would look like, and who would call the shots.

To conclude, I recommend this book for the wealth of information that it contains about the various Islamists, their lives and times, and the extent to which they have influenced state policies and each other. But at the same time, I believe that Shehadeh's investigation would have had a stronger impact if she had contextualized her argument within an examination of globalization and its effects on rising revivalism in various religious traditions, as well as their links to local and global patriarchies. On an editorial note, I found repetitions throughout the manuscript, the most glaring of which is on page 28 , where a substantial quote by al-Mawdudi is presented and then repeated on pages 44-45.

Shahnaz Khan Assistant Professor, Global Studies and Women's Studies Program Wilfred Laurier University Waterloo, Ontario, Canada 